Journal of Theoretical and Applied Economics
(ISSN:2576-3970)

\title{
DETERMINANTS OF MOBILE PHONE DEMAND AMONG RESIDENTS OF CENTRAL REGION OF ERITREA
}

\section{Fitsum Ghebregiorgis ${ }^{1}$ and Habteab Tekie Mehreteab ${ }^{2}$}

${ }^{1}$ Department of Business Management and Marketing, College of Business and Economics ${ }^{2}$ Department of Economics, College of Business and Economics (All authors contribted equally. Arrangement of names is a matter of alphapetical order)

\section{ABSTRACT}

The study endeavors to investigate the determinants of mobile phone usage (adoption) using data from Central Region in Eritrea. Data were collected by distributing questionnaire to a sample of 450 individuals selected at random using the accidental technique. A close ended questionnaire was used and the questionnaire captured individual characteristics and views on the use of mobile phone. The questionnaire was administered over a period of twelve weeks. Many and very significant conclusions are derived from this research. It has been found that the majority of respondents use the mobile phone; the main reason for having a mobile is because they want to have it; the most important reason for having a mobile phone is to easily communicate with friends or relatives; the main purpose of using mobile phone sets always are making local calls. It is also interesting to note that some respondents never used their mobile for sending text messages; perhaps this is related with the illiteracy rate in the country. The findings show that certain variables such as gender and income are important predicators of mobile usage in Eritrea. The empirical results show that age and educational level were not significant in explaining variations among mobile users.

Key words: Ownership, Mobile usage, Eritrea
*Correspondence to Author: Fitsum Ghebregiorgis (address for correspondence), College of Business and Economics, P.O. Box 3963, Asmara, Eritrea (Tel: + 291716 1013).

\section{How to cite this article:}

Fitsum Ghebregiorgis and Habteab Tekie Mehreteab. DETERMINANTS OF MOBILE PHONE DEMAND AMONG RESIDENTS OF CENTRAL REGION OF ERITREA. Journal of Theoretical and Applied Economics, 2017; 1:2.

\section{eSciencePublisher。}

eSciPub LLC, Houston, TX USA. Website: http://escipub.com/ 


\section{BACKGROUND OF THE STUDY}

A mobile phone (also known as a cellular phone and a hand phone) is a device which can make and receive telephone calls over a radio link whilst moving around a wide geographic area. Recent studies suggest that mobile phone has evolved into something more than a simple communication tool, gaining its own place in various aspects of social interaction. Mobile devises seems to have invaded the universe. At every turn, you see a mobile devise in use by someone. This technology has permeated even such distant reaches of the world as never imagined before.

People are using mobile phones not only voice communication but also other purposes as Short Message Services (SMS), Multimedia Message Services (MMS), recording, calculating, playing games etc. Over the same time period, mobile phones have spread from urban centers to rural areas as well as from the wealthy to the poor in developing countries (Aker and Mbiti, 2010). Moreover, mobile phones are often the only form of telecommunication to be found in rural areas of developing countries (Donner, 2008). Many individuals and households throughout the developing world have thus "leapfrogged" fixedline telephone technology altogether in order to directly adopt mobile phone technology.

The development of mobile phones and technologies has been an extended history of innovation and advancements cropped up due to dynamic changes in consumers' needs and preferences. Among these developments, mobile phone devices have had one of the fastest household adoption rates of any technology in the world's modern history (Comer and Wikle, 2008).

The last decade has seen a rapid growth in the number of mobile phones in developing countries. According to the International Telecommunication Union (ITU), one individual in 20 subscribed to mobile phones throughout the world in 1998. By 2008, that figure had climbed to almost 12 individuals in 20, with developing countries accounting for almost two thirds of mobile-phone use in 2008 compared with less than half in 2002 (ITU, 2009). By 2010 it is reported that the number mobile subscription has reached to 5.3 billion. This is approximately the equivalent of 77 percent of the world population. This represents a huge increase from 4.6 billion mobile subscriptions at the end of 2009.

Africa has not been left out in the last decade; but it has rather experienced a mobile telephone revolution. These mobile phone service accesses become even more pronounced when considering the fact that mobile phone in Africa may be shared with family members, friends or neighbors (James, 2011). Over time, the discrepancies in mobile phone penetration rates between the developed world and African nations have been narrowing, a trend accelerated by the fact that African mobile phone operators have during the past few years made considerable investments to extend the geographic coverage of their networks.

Eritrea, about a decade has seen tremendous growth in the mobile phone industry. Today, a mobile phone is no longer the rich man's preserve accessory in Eritrea. People of different ages, economics status, educational qualification, and gender now own and use mobile phones. In Eritrea, mobile phone penetration rate has increased to more than 25 fold, that is, from 20,000 users in 2006 to more than 520,000 users in 2017. It seems as if almost everyone has a mobile phone in his or her pocket. The first mobile phone service in Eritrea was initiated by the Government of the State of Eritrea in 2004.

The mobile phone itself offers several positive impacts to our lives. Waverman et al (2005) investigate the role of mobile phones in developing economies and find that they are playing the same crucial role that fixed telephony played in developed economies in the 1970s and 1980s. Their study covered 38 developing countries for the period 1996 to 2003 and provides evidence of the strong impact of mobile in developing countries. 
The mobile phone has allowed us to create a network of communications. According to, it is the very essence of mobility in media as it allows instantaneous interactive communication over long distances. The mobile phone device offers us security, safety, accessibility and other benefits. It is also seen as a possibility of spurof-the-moment business or casual meetings. Moreover, the use of mobile phone can progressively reduce the costs of managing information, enabling individuals and organizations to undertake information-related tasks much more efficiently, and to introduce innovations in products, processes and organizational structures in any sector.

As a result, the mobile phone is the most rapidly adopted information communication technology (ICT) in the world. For example, the Millennium Village Project (MVP) introduced village mobile phones to monitor health indicators (MVP, 2010). Likewise, Grameen claims that "mobile phones not only create a new business opportunity for the poor, but also bring access to information, market, health and other services to the remote rural areas" (Grameen, 2007).

Lastly, new nongovernmental organizations (NGOs) such as Mobile Active have emerged in response to the presumed beneficial impact of mobile phones on the poor, and the United Nations encourages the use of mobile phones as a means of achieving the Millennium Development Goals.

Despite the excitement surrounding mobile phone technology, there certain questions which remained unanswered such which group or stratum of society are the active users; are they the educated, male, the young, the rich or the other way round the illiterate, female, the old, the poor, minorities etc,. It is the objective of this paper to find answers to these questions and it is the right time that our policy makers have the answers over this and other similar issues to take appropriate measures in the future.

\section{LITERATURE REVIEW}

Though the number of studies focused on mobiles in the developing world is growing steadily, these studies have appeared in relative isolation from each other, separated by regions, and by disciplines. Many research communities are interested in the topic: those impressed by the function of market mechanisms underpinning the stunning spread of a new technology across the planet; those concerned with economic development that see the mobile as an enabler of broad-based prosperity; and those concerned with describing the social, and cultural implications of its use. By focusing on areas where economic constraint is a pressing concern, and by extending analysis to a broader range of cultural and social contexts, these researchers are contributing to a broader, more varied understanding of the implications of mobile and personal communication technologies.

The majority of studies carried out to define the determinants behind adopting and using mobile phone have focused on the industrialized world and many of these studies try to compare the rate of adoption across countries. The primary explanatory factors resulting from these investigations were: per capita income, average level of education (i.e. human capital), degree of competition, and the density and quality of telecommunication infrastructure.

Some of the literature to date which is done on specific developed countries has found that mobile phone demand to be primarily a function of price and a set of socio-demographic variables. Hausman (1999) found income a significant variable to explain aggregate mobile demand. Similarly, Garbacz and Thompson (2007) found income and education to be drivers of national mobile demand. Ahn, Han, and Lee (2006) found gender to be statistically significant in explaining customer mix. Regarding the impact of gender, a number of studies (e.g. Bimber 2000; Schumacher and Morahan-Martin (2001)) have demonstrated that during the initial phases of introducing new technology, the first movers tend most often to be men. Over time 
however as the technology is disseminated, the gap between men and women narrows.

Aker and Mbiti (2010) referenced a survey conducted in Kenya devoted to generating a mobile phone user profile. This survey indicated that in 2006, users tended to be young, urban, educated and high income earners. The 2009 survey update highlighted the strength of mobile phone penetration in rural zones as well as among the poorer and less well-educated population segments, providing a sign that access inequalities to mobile phone service have narrowed.

Piccoliet al (2001) established that the education level of an individual influences ICTs adoption and usage, through influencing an individual's capability to use technology. Gender and technology studies have found that men and women adopt and use technology differently (Gefen and Straub, 1997; Venkateshand Morris, 2000). Men's decisions to use technology are more strongly influenced by their perception of usefulness, while women's decisions are based more on perceptions of the technology's ease of use (Venkatesh and Morris, 2000).

The youth was very quick in the adoption of the mobile phone even before it has been in existence for about a decade. Reduction in costs, size and the introduction of the pre-paid phone card in the 1990's contributed to the surprisingly rapid adoption rate by young people. The world over, the rates of mobile phone use amongst young people is on the increase. Even though the use of mobile phone would have been linked to business activities, research has shown that the age groups $16-24$ years are the most prevalent users. According to the choice of mobile phones based on features and attributes are influenced by demographic factors.

The theory of technology use also points to age as a factor that influences when and how an individual uses technologies. Some studies indicate that age is a key factor in the use of technology, with younger people tending to exhibit higher use levels. Consequently, these individuals tend to use ICTs technologies more than older users.

A considerable body of work has revealed the influence of social neighborhood in the decision to adopt a new technology, especially when network effects play a substantial role (Goolsbee and Zittrain, 1999; Coneus and Schleife, 2010, Liu and San, 2006; Ward, 2010). The social network, through providing advice, is capable of reducing costs or increasing the benefits derived from the use of technologies like mobile phones. Social interactions and social learning become determinant factors, especially during the technological startup phase. Along these lines, Goldfarb (2006) showed that the use of e-mail services in the United States began in universities and spread via students who went on to become influencers within their own households. Moreover, the density of an individual's social network (or his/her amount of social capital) can also promote mobile phone adoption, by means of strengthening network externalities and thus raising the gains expected from these technologies (Franzen 2003; Pénard and Poussing, 2010).

The 21st century can be interpreted as infocommunication age. When new communication technologies spread among the people, one of them is the mobile communication. Intellectuals have started to ask that why someone decides to use or not use a mobile device. Which parameters are important in the decision, and which are not? How we use the new technologies in everyday life? When and for what purpose we use it because.

\section{RESEARCH METHODOLOGY}

The study attempts to measure the determinants of mobile usage in Eritrea. To conduct the study, primary and secondary sources of information were used. The selected population includes several categories of mobile users such as students, employees in the formal and informal sector, public and private sector employees, unemployed, house maids, and daily laborers'. Simple random sampling method is employed to select respondents in the Central Region, where Http://escipub.com/journal-of-theoretical-applied-economics/ 
the capital city is located. A total of 450 respondents are included in this study. Primary data were gathered in a three months period between January 2017 and March 2017. The questionnaires were filled by 12 enumerators with management and marketing background. This study is quantitative and descriptive in nature. It is conducted based on primary and secondary data. To execute the purpose of the study, field survey method is used to collect primary data by taking direct interviews through the questionnaire. The study survey incorporated two demeanor estimation questions, including some demographic inquiries to improve a better understanding about the study result. Secondary data has been extracted from various sources such as journal articles, textbooks, website, etc. The collected data are analyzed by various statistical tools and techniques including frequency distribution through data processing software SPSS version 23.

\section{DISCUSSIONS AND RESULTS}

\section{Demographic Characteristics}

Of the total respondents 60.4 percent $(n=272)$ are male and 39.6 percent $(n=178)$ are females. The age of respondents belongs to 15-24 years 33.6 percent, 25-34 years 27.8 percent, 35-44 years 19.1 percent, 45-54 years 10.7 percent, above 55 years 8.9 percent. Regarding religion, 89.1 percent are Christians, while 10.9 percent are Muslims. As far as marital status is concerned, 51.8 percent are single, 41.3 percent are married, 2.7 percent divorced, 1.3 percent are separated and 2.9 percent are widowed.
Household size represents that, 32.7 percent are with 1-3 people, 45.6 percent have 4-6 people, 16.2 percent consist of 7-9 people and 5.6 percent with 10-14 people. Educational level of the respondents shows that 32.1 percent are high school students (9-12 grade), 30.4 percent certificate and diploma graduates, 25.2 percent of having first degree and above graduates, 6.5 percent having elementary education level (1-6 grade), and 5.8 percent of junior education (grade 7-8). Occupational status of respondents indicates that 62.9 percent have formal job, 13.3 percent are in the informal sector, and 12.7 percent are students, while 11.1 percent are unemployed. Of those who work in the formal sector, 70.5 percent of them work in the public sector, and the remaining 29.5 percent work in the private sector. The analysis also illustrates that 24.2 percent of respondents between the income brackets of 1001-2000 Nakfa ${ }^{1}, 22.2$ percent earning between 501 to 1000 Nakfa, 13.1 percent having income 2001-3000 Nakfa, 4.9 percent with income of $3001-4000,3.6$ percent between income brackets of 4001-5000 Nakfa, 6 percent with an income of above 5000 Nakfa. The study also shows that although 5.3 percent have an income of less than 500 Nakfa, a significant amount of respondents, that is, 20.7 percent do not have income.

\section{OWNERSHIP AND MONTHLY EXPENSES ON MOBILE USAGE}

The mobile ownership status shows that of the total 450 respondents, about 90 percent own mobile phone, whereas the remaining 10.2 percent do not own as can be seen from Table 1 below.

Table 1: Mobile ownership

\begin{tabular}{|c|c|c|}
\hline Own mobile & Percentage & Number \\
\hline Yes & 89.8 & 404 \\
\hline No & 10.2 & 46 \\
\hline Total & $\mathbf{1 0 0 . 0}$ & $\mathbf{4 5 0}$ \\
\hline
\end{tabular}

Source: Data survey (2017)

${ }^{1} 1$ US dollar $=15$ Eritrean Nakfa

Http://escipub.com/journal-of-theoretical-applied-economics/ 
In Eritrea people use scratch cards for making a month to more than ten (10) cards of 110 Nakfa mobile phone calls. There are three (3) a month. Further observation indicates that the categories of prepaid cards with 55 Nakfa, 110 most frequently expended amount in a month is Nakfa, and 330 Nakfa. As can be seen from 110 Nakfa, other amounts that are commonly Table 2, among those who own mobile phones, their monthly expenditure on mobile cards varies considerably, ranging from one card of $55 \mathrm{Nakfa}$ paid for a mobile card in a month include 220 Nakfa and 55 Nakfa.

\section{Table 2: Monthly expenditure}

\begin{tabular}{|l|l|l|}
\hline Monthly amount spent on mobile $(\mathrm{Nkf})$ & Percentage & Number \\
\hline 55.00 & 11.9 & 48 \\
\hline 110.00 & 33.7 & 136 \\
\hline 165.00 & 6.9 & 28 \\
\hline 220.00 & 25.0 & 101 \\
\hline 275.00 & .5 & 2 \\
\hline 330.00 & 8.4 & 34 \\
\hline 440.00 & 4.0 & 16 \\
\hline 550.00 & 3.5 & 14 \\
\hline 660.00 & 1.0 & 4 \\
\hline 770.00 & .2 & 1 \\
\hline 880.00 & .7 & 3 \\
\hline 990.00 & 1.0 & 4 \\
\hline 1100.00 & 2.0 & 8 \\
\hline 1210.00 & .5 & 2 \\
\hline 1430.00 & .2 & 1 \\
\hline 1650.00 & .2 & 1 \\
\hline 1980.00 & .2 & 1 \\
\hline Total & 100.0 & 404 \\
\hline
\end{tabular}

Source: Data survey (2017)

COSTS AND COMMON TYPES OF preferred mobile phone among the respondents PREFERRED HANDSETS are Samsung (43.8 percent) and Nokia (36.9 Respondents were asked to indicate which percent). Table 3 below provides the results. brand name they prefer, the most frequently

Table 3: Preferred brands

\begin{tabular}{|l|l|l|}
\hline Mobile Brand & Percentage & Number \\
\hline Nokia & 36.9 & 149 \\
\hline S-Ericsson & 1.0 & 4 \\
\hline
\end{tabular}




\begin{tabular}{|l|l|l|}
\hline Motorola & 0.7 & 3 \\
\hline Samsung & 43.8 & 177 \\
\hline LG & 2.2 & 9 \\
\hline Siemens & 0.0 & 0 \\
\hline I phone & 5.4 & 22 \\
\hline Others & 9.9 & 40 \\
\hline Total & $\mathbf{1 0 0 . 0}$ & $\mathbf{4 0 4}$ \\
\hline
\end{tabular}

Source: Data survey (2017)

As Table 4 below shows, in terms of costs mobile or Smart Phones from families or (purchase prices), on average the least relatives living abroad (Europe or United States expensive are the Nokia brand. Although the of America), which is common phenomenon in purchase prices by an African standard is very the least developing countries. expensive, most people in Eritrea get expensive

Table 4: Mobile brands and purchase prices

\begin{tabular}{|l|l|l|l|l|l|}
\hline \multirow{2}{*}{$\begin{array}{l}\text { Type of mobile } \\
\text { phone }\end{array}$} & $\begin{array}{l}\text { Percent of respondents } \\
\text { who own }\end{array}$ & Purchase Price & \multicolumn{2}{l}{} \\
\cline { 5 - 6 } & 36.9 & 500 & 7000 & 1834.74 & 1193.146 \\
\hline Nokia & 1.0 & 1500 & 2000 & 1825.00 & 236.291 \\
\hline S-Ericsson & 0.7 & 3000 & 10000 & 6333.33 & 3511.885 \\
\hline Motorola & 43.8 & 1000 & 48000 & 7132.95 & 7463.224 \\
\hline Samsung & 2.2 & 2000 & 25000 & 9722.22 & 8177.221 \\
\hline LG & 5.4 & 7000 & 45000 & 19113.64 & 11598.370 \\
\hline I Phone & 9.9 & 2000 & 25720 & 9379.47 & 5646.516 \\
\hline Others & & & & & \\
\hline
\end{tabular}

Source: Data survey (2017)

REASONS FOR PURCHASE AND COMMON USE OF MOBILE PHONE

Table 5 below presents the percentage distribution of respondents who own mobile with respect the reason for having a mobile. A little more than half $(52.2 \%)$ of the respondents who own a mobile, they had mobile because they wanted to have one and other significant respondents stated that because of other reasons $(30.2 \%)$.

Table 5: Reasons for purchase

\begin{tabular}{|l|l|l|}
\hline Main reason for purchasing a mobile & Percentage & Number \\
\hline Everybody around had one & 6.7 & 27 \\
\hline Wanted to have it & 52.2 & 211 \\
\hline Somebody persuaded me to have one & 10.9 & 44 \\
\hline
\end{tabular}




\begin{tabular}{|l|l|l|}
\hline Other reasons & 30.2 & 122 \\
\hline Total & $\mathbf{1 0 0 . 0}$ & $\mathbf{4 0 4}$ \\
\hline
\end{tabular}

Source: Data survey (2017)

Furthermore, according to the responses of the respondents who own mobile, the most important reason for having a mobile phone that was mentioned more number of times was that a mobile phone enables one to easily communicate with friends or relatives (49.0\%), followed by 'mobile enables one to be easily accessible to others' $(25.0 \%)$. Table 6 provides the reasons for having mobile phones.

Table 6: Reasons for having mobile phones

\begin{tabular}{|l|l|l|}
\hline Most important reason for having mobile phone & Percentage & Number \\
\hline Gives the convenience of calling anytime & 13.1 & 53 \\
\hline Makes you easily accessible to others & 25.0 & 101 \\
\hline It's better medium to get message fast & 7.2 & 29 \\
\hline It's easy for communicating with friends/relatives/workplace & 49.0 & 198 \\
\hline I have no fixed landline at home or workplace & 2.5 & 10 \\
\hline Any other & 3.2 & 13 \\
\hline Total & $\mathbf{1 0 0 . 0}$ & $\mathbf{4 0 4}$ \\
\hline
\end{tabular}

Source: Data survey (2017)

\section{PURPOSE OF USING MOBILE PHONE SETS}

Respondents were asked the purpose of using mobile phone sets such as voice recording, texting messages, internet ...etc. Table 7 below shows the percentage distribution of respondents who own mobile with respect to how frequently do they use their mobile for its various functions. It is interesting to note that about $16 \%$ of the respondents have responded that they never used their mobile for sending text messages; perhaps this is related with the illiteracy rate in the country.

Table 7: Frequency of mobile phone use

\begin{tabular}{|l|l|l|l|l|l|l|}
\hline & Always & Often & Sometimes & Seldom & Never & Total \\
\cline { 2 - 7 } & Percent & Percent & Percent & Percent & Percent & Percent \\
\hline Sending text messages & 33.5 & 13.6 & 27.0 & 9.9 & 15.9 & 100.0 \\
\hline Sending pictures & 4.7 & 6.7 & 12.6 & 11.6 & 64.4 & 100.0 \\
\hline Playing games & 12.1 & 7.9 & 16.3 & 14.6 & 49.0 & 100.0 \\
\hline Local calls & 82.2 & 11.4 & 5.2 & 0.7 & 0.5 & 100.0 \\
\hline International calls & 16.1 & 13.4 & 28.5 & 23.0 & 19.1 & 100.0 \\
\hline Listening to music & 39.4 & 8.7 & 21.8 & 6.9 & 23.3 & 100.0 \\
\hline Taking pictures & 22.5 & 16.6 & 25.2 & 8.2 & 27.5 & 100.0 \\
\hline Browsing the internet & 15.8 & 15.1 & 13.1 & 5.4 & 50.5 & 100.0 \\
\hline
\end{tabular}




\begin{tabular}{|l|l|l|l|l|l|l|}
\hline Organizing appointments & 24.5 & 14.9 & 17.1 & 14.6 & 29.0 & 100.0 \\
\hline Others & 9.8 & 19.3 & 23.9 & 11.8 & 35.2 & 100.0 \\
\hline
\end{tabular}

Source: Data survey (2017)

In addition, in order to measure the degree of addiction of users of mobile phone, respondents were asked to indicate whether they are able to stay a single day without using mobile.
According to the results, about half of the respondents who own mobile said that they cannot stay for a day without their phone. Table 8 below provides the results.

Table 8: Degree of stay without mobile phone

\begin{tabular}{|l|l|l|}
\hline Stay without mobile for a day & Percentage & Number \\
\hline Yes & 49.9 & 201 \\
\hline No & 50.1 & 202 \\
\hline Total & $\mathbf{1 0 0 . 0}$ & $\mathbf{4 0 3}$ \\
\hline
\end{tabular}

Source: Data survey (2017)

We also presented respondents with certain statements to indicate their agreement or disagreement in order to identify their opinion with regard to mobile phone usage. The largest majority (92.6 percent) indicated that they totally agree that mobile phone has become a necessity currently. In addition, majority of respondents (75.2 percent) totally disagree that using mobile phone while driving a car is okay; and significant amount of respondents (32.1 percent) again totally disagree that lengthy conversation on mobile phone is okay. Table 9 below presents the results.

\section{Table 9: Mobile phone usage}

\begin{tabular}{|l|l|l|l|l|l|l|}
\hline Statements & $\begin{array}{l}\text { Totally } \\
\text { agree }\end{array}$ & $\begin{array}{l}\text { Somewh } \\
\text { at agree }\end{array}$ & Neither & $\begin{array}{l}\text { Somewh } \\
\text { at } \\
\text { disagree }\end{array}$ & $\begin{array}{l}\text { Totally } \\
\text { disagree }\end{array}$ & Total \\
\cline { 2 - 7 } & Percent & Percent & Percent & Percent & Percent & Percent \\
\hline $\begin{array}{l}\text { Mobile phone has } \\
\text { become necessary } \\
\text { today }\end{array}$ & 92.6 & 6.0 & 0.5 & 0.0 & 1.0 & 100.0 \\
\hline $\begin{array}{l}\text { Using mobile phone } \\
\text { while driving is ok }\end{array}$ & 2.5 & 6.0 & 5.0 & 11.4 & 75.2 & 100.0 \\
\hline $\begin{array}{l}\text { Lengthy conversation on } \\
\text { mobile phone is ok }\end{array}$ & 8.5 & 22.9 & 19.4 & 17.2 & 32.1 & 100.0 \\
\hline
\end{tabular}

Source: Data survey (2017)

Finally, we asked respondents the reasons for not owning a mobile phone. The following table presents the percentage distribution of the respondents who do not own mobile. As can be seen from Table 10, the most commonly cited reason for not owning a mobile is that mobile is 
too costly for them (51.5\%). Among those who have plans to buy mobile phones in the near do not have mobile phones, 27 out of 46 of them future.

Table 10: Reasons for not having mobile phone

\begin{tabular}{|l|l|l|}
\hline Reason for not having mobile & Percentage & Number \\
\hline Not allowed & 11.1 & 5 \\
\hline Don't require it & 20.0 & 9 \\
\hline It is costly & 51.5 & 23 \\
\hline Don't want to be reached all the time & 13.3 & 6 \\
\hline Other reasons & 4.4 & 2 \\
\hline Total & $\mathbf{1 0 0 . 0}$ & $\mathbf{4 5}$ \\
\hline
\end{tabular}

Source: Data survey (2017)

DETERMINANTS FOR HAVING MOBILE Logistic Regression estimates for possession of PHONE mobile phone (dependent variable: 1 if do own mobile, 0 if don't own mobile) ( $n=448)$.

\begin{tabular}{|l|l|l|l|l|l|l|}
\hline Independent variables & B & S.E. & Wald & df & Sig. & Exp(B) \\
\hline Age & -.018 & .022 & .672 & 1 & .412 & .982 \\
\hline Gender(male) & .010 & .390 & .001 & 1 & .980 & 1.010 \\
\hline Marital Status & & & 1.307 & 2 & .520 & \\
\hline \multicolumn{1}{r|}{ Marital Status (married) } & .492 & .550 & .803 & 1 & .370 & 1.636 \\
\hline $\begin{array}{c}\text { Marital status } \\
\text { (divorced/widowed) }\end{array}$ & .962 & .883 & 1.189 & 1 & .276 & 2.618 \\
\hline Birthplace (born inside Eritrea) & -19.045 & 5497.657 & .000 & 1 & .997 & .000 \\
\hline Occupation & & & 3.802 & 3 & .284 & \\
\hline \multicolumn{1}{|c|}{ Occupation (Informal) } & .075 & .559 & .018 & 1 & .893 & 1.078 \\
\hline \multicolumn{1}{c|}{ Occupation(Unemployed) } & .255 & .582 & .192 & 1 & .662 & 1.290 \\
\hline \multicolumn{1}{c|}{ Occupation(Student) } & -.856 & .511 & 2.804 & 1 & $0.09^{*}$ & .425 \\
\hline Education & .183 & .053 & 11.853 & 1 & $0.00^{\star \star \star}$ & 1.200 \\
\hline Income & .000 & .000 & 3.965 & 1 & $0.04^{\star *}$ & 1.000 \\
\hline Constant & 18.960 & 5497.657 & .000 & 1 & .997 & 171500200.492 \\
\hline
\end{tabular}

Note: Coefficients are marginal effects. For dummy variables, the marginal effect refers to effect of discrete change in the dummy variable from 0 to 1 . Omitted categories include female gender, Single marital status, Born outside Eritrea Birth place, formal occupation. ${ }^{*} p<0.1,{ }^{* *} p<0.05,{ }^{* * *} p<0.01$.

OLS estimates of conditional demand for mobile cards, dependent variable Ln (expenditure on mobile cards in a month). 
Salleh et al., JTAE, 2017; 1:1

\begin{tabular}{|l|l|l|l|l|l|}
\hline \multirow{2}{*}{ Independent v. } & \multicolumn{2}{|l|}{$\begin{array}{l}\text { Unstandardized } \\
\text { Coefficients }\end{array}$} & \multicolumn{2}{l|}{$\begin{array}{l}\text { Standardized } \\
\text { Coefficients }\end{array}$} & \multirow{2}{*}{} \\
\cline { 2 - 4 } & $\mathrm{B}$ & Std. Error & Beta & $\mathrm{t}$ & Sig. \\
\hline (Constant) & 4.942 & .239 & & 20.671 & .000 \\
\hline Age & -.001 & .003 & -.015 & -.299 & .765 \\
\hline Gender (male) & .323 & .076 & .211 & 4.253 & .000 \\
\hline Birthplace (born inside Eritrea) & -.184 & .105 & -.079 & -1.749 & .081 \\
\hline Household size & .011 & .014 & .038 & .804 & .422 \\
\hline Occupation & & & & & \\
\hline Occupation (Informal) & .280 & .106 & .128 & 2.650 & .008 \\
\hline Occupation (Unemployed) & -.065 & .128 & -.026 & -.506 & .613 \\
\hline Occupation (student) & -.194 & .117 & -.083 & -1.653 & .099 \\
\hline Education & .005 & .012 & .023 & .439 & .661 \\
\hline Income & $3.756 \mathrm{E}-05$ & .000 & .328 & 7.088 & .000 \\
\hline
\end{tabular}

Adj. R-square=0.207. Omitted categories include female in gender, Born outside Eritrea in birthplace, and Formal in occupation. ${ }^{*} p<0.1,{ }^{* *} p<0.05,{ }^{* * *} p<0.01$. OLS Ordinary Least Square.

OLS estimates of conditional demand for mobile cards, Dependent variable Monthly expenditure on mobile cards (in Nakfa).

\begin{tabular}{|c|c|c|c|c|c|}
\hline \multirow[b]{2}{*}{ Independent v. } & \multicolumn{2}{|c|}{$\begin{array}{l}\text { Unstandardized } \\
\text { Coefficients }\end{array}$} & \multirow{2}{*}{$\begin{array}{l}\text { Standardized } \\
\text { Coefficients } \\
\text { Beta }\end{array}$} & \multirow[b]{2}{*}{$\mathrm{t}$} & \multirow[b]{2}{*}{ Sig. } \\
\hline & B & Std. Error & & & \\
\hline (Constant) & 1.965 & .661 & & 2.971 & .003 \\
\hline Age & -.007 & .009 & -.039 & -.851 & .395 \\
\hline Gender (male) & .826 & .210 & .177 & 3.930 & .000 \\
\hline Birthplace (born inside Eritrea) & -.677 & 291 & -.096 & -2.325 & .021 \\
\hline Household Size & .045 & .038 & .050 & 1.170 & .243 \\
\hline \multicolumn{6}{|l|}{ Occupation } \\
\hline Occupation (Informal) & .661 & .293 & .099 & 2.259 & .024 \\
\hline Occupation (Unemployed) & .194 & .354 & .026 & .550 & .583 \\
\hline Occupation (Student) & -.048 & .325 & -.007 & -.147 & .883 \\
\hline Education & -.015 & .032 & -.023 & -.474 & .635 \\
\hline Income & .000 & .000 & .530 & 12.608 & .000 \\
\hline
\end{tabular}

Adj. R-square $=0.345$. Omitted categories include female in gender, born outside Eritrea in birthplace, and Formal in occupation. ${ }^{*} p<0.1,{ }^{* *} p<0.05,{ }^{* *} p<0.01$. OLS Ordinary Least Square.

OLS estimates of conditional demand for mobile cards, Dependent variable expenditure on mobile cards in a month). 


\begin{tabular}{|c|c|c|}
\hline Independent v. & Lin-Lin Model & Ln-Lin Model \\
\hline Age & $-0.007(-0.851)$ & $-0.001(-0.299)$ \\
\hline Gender (male) & $0.826^{\star \star \star}(3.93)$ & $0.323^{\star \star \star}(4.253)$ \\
\hline Birthplace (born inside Eritrea) & $-0.677^{\star *}(-2.325)$ & $-0.184^{*}(-1.749)$ \\
\hline Household Size & $0.045(1.170)$ & $0.011(0.804)$ \\
\hline \multicolumn{3}{|l|}{ Occupation } \\
\hline Occupation (Informal) & $0.661^{* *}(2.259)$ & $0.280^{\star \star \star}(2.65)$ \\
\hline Occupation (Unemployed) & $0.194(0.550)$ & $-0.065(-0.506)$ \\
\hline Occupation (Student) & $-0.048(-0.147)$ & $-0.194^{\star}(-1.653)$ \\
\hline Education & $-0.015(-0.474))$ & $0.005(0.439)$ \\
\hline Income & $0.00018^{* \star *}(12.608)$ & $0.00004^{\star \star \star}(7.088)$ \\
\hline (Constant) & $1.965^{\star \star \star}(2.971)$ & $4.942^{\star * \star}(20.671)$ \\
\hline Adj. R-square & 0.345 & 0.207 \\
\hline
\end{tabular}

The $t$ statistics of the coefficients are in parentheses. Omitted categories include female in gender, born outside Eritrea in birthplace, and formal in occupation: ${ }^{*} p<0.1,{ }^{* *} p<0.05,{ }^{* * *} p<0.01$.

To identify the factors that determine the usage of mobile phone, regression analysis was carried out, where the dependent variable is the amounts spend on mobile cards per month, and the independent variables are selected from the background characteristics of respondents which include age, gender, educational level and income. The results show that there is a positive relationship between income and the amount spend on mobile cards, and the relationship is highly significant $(p$-value $=0.0)$. There is also significant difference in the expenditure levels on mobile cards between males and females, with females, on average, spending more than males. However, there is no significant difference between age and educational qualification of the respondents. Thus, there is no positive relationship between mobile usage and age and educational level of users.

\section{CONCLUSIONS AND RECOMMENDATIONS}

This paper represents an important first step in understanding the determinants of mobile usage in Eritrea from an African context. The findings show that certain variables such as gender and income are important predicators of mobile usage in Eritrea. The empirical results show that all independent variables were not significant in explaining variations among mobile users.

Many and very significant conclusions are derived from this research. It has been found that the majority of respondents use the mobile phone (about 90 percent); the main reason for having a mobile is because they want to have it (52.2 percent); the most important reason for having a mobile phone is to easily communicate with friends or relatives (49.0\%); the main purpose of using mobile phone sets always are making local calls (82.2 percent). It is also interesting to note that about $16 \%$ of the respondents have responded that they never used their mobile for sending text messages; perhaps this is related with the illiteracy rate in the country.

In addition, the largest majority (92.6 percent) indicated that they totally agree that mobile phone has become a necessity currently. In addition, majority of respondents (75.2 percent) totally disagree that using mobile phone while driving a car is okay; and significant amount of respondents (32.1 percent) again totally disagree that lengthy conversation on mobile phone is okay. On the other hand, the most 
commonly cited reason for not owning a mobile is that mobile is too costly for them (51.5\%).

However, this study has some limitations. The survey was carried out in a sample of 450 people. Perhaps, the survey should be repeated using a larger sample for better results. The survey was based on a certain determinants of mobile usage model. Even though useful conclusions were drawn, the inclusion of some other factors could improve the model. Since most people from the sample, own telephone and non-owners are too small, that may have had an impact on their answers.

Finally, this research work is exploratory and much remains to be understood about the pattern and usage of mobile phone.

\section{REFERENCES}

Ahmed, I. and Qazi, F.T.(2011) "Mobile Phone Adoption and Consumption Patterns of University Students in Pakistan" International Journal of Business and Social Sciences. Vol 2,No.9,pp. 205213.

Bimber, B., (2000), Measuring the Gender Gap on the Internet.Social Science Quarterly, 81(3), 868-876.

Comer, J. and Wikle, T. (2011), Worldwide Diffusion of Cellular Telephone, 1995-2005. The Professional Geographer. 60 (2), 252-269.

Coneus, K., Schleife, K. (2010), "Online But Still Divided - Inequality in Private Internet Use in Developing Countries" in Africa: The Economic Impact of Mobile Phones. Vodafone Policy Divide", Technological Forecasting and Social Change, Vol. 78, pp. 729-735.

Donner, J. (2008), Research Approaches to Mobile Use in the Developing World: A Review of the Literature. The Information Society: An International Journal. 24 (3), 140-159.

Duncombe R, Kintu R and Nakangu B, (2006). ECommerce for Small Enterprise Development $A$ Handbook for Entrepreneurs in Developing Countries.

Economic Perspectives, Vol. 24, N`3, pp 207232.Economic Statistics 17:188-194.Experiences", Computers in Human Behavior, Vol. 17, №1, pp. 95110.

Garbacz, C., and Thompson, H. G., Jr. (2007). Demand for telecommunication services in developing countries. Telecommunications Policy 31 (2007) 276289.
Gefen, D. and Straub, D. (1997). Gender difference in the perception and use of e-mail: an extension to the technology acceptance model. MIS Quarterly, 21, 389- 400.

Germany",

ZentrumfürEuropäischeWirtschaftsforshungGmbh (ZEW), Discussion Paper

GOOLSBEE., A. and ZITTRAIN, J., (1999). Evaluating the Costs and Benefits of Taxing Internet Commerce.National Tax Journal, 52, 413-428.

Grameen Bank (2011) Village phones, http://www.grameeninfo.

org/index.php?option=com_contentandtask=viewandi $d=681$ andltemid $=676$.

Grameen Technology Center, 2005, IVillage phone replication manual," Grameen Foundation USA, http://www.itu.int/ITU-

D/ict/material/Telecom09_flyer.pdf accessed May 17, 2011.

http://www.millenniumvillages.org/progress/

accessed May 17, 2011International Journal of Industrial Organization, Vol. 24, pp. 203-225.

International Telecommunications Union (2009), the world in 2009: ICT facts and figures,

International Telecommunications Union,ITU 2013."World Telecommunications Indicators Database" International Telecommunications Union. Geneva.

James, J. (2011), "Sharing Mobile Phones in Developing Countries: Implications for the Digital, Journal of Economic Issues, Vol. XLIV, №3, pp. 568594.

Liu, M. C., San, G. (2006), "Social Learning and Digital Divides: a Case Study of Internet mediation effects of partial defection in the Korean mobile telecommunications service industry." Telecommunications Policy 30:552-568.

Millennium Villages Project (2010) Achieving the goals: progress to date,

Muto, M. and Yamano, T. (2009) The Impact of Mobile Phone Coverage Expansion on Market $\mathrm{N}^{\circ} 10-042$, Available at ftp://ftp.zew.de/pub/zewdocs/dp/dp10042.pdf Paper Series, Number 3.Participation: Panel Data Evidence from Uganda. World Development 37(12), pp. 1887-96.

Pénard, T., Poussing, N. (2010), "Internet Use and Social Capital: The Strength of Virtual Ties",

Piccoli, G., Ahmed, R. and Ives, B. (2001). Web based virtual learning environments: a research framework and a preliminary assessment of effectiveness in basic IT skills training. MIS Quarterly, 25, 401-426. 
Schumacher, P., Morahan-Martin, J. (2001), "Gender, Internet and Computer Attitudes and SSRN: http://ssrn.com/abstract=1619847 or http://dx.doi.org/10.2139/ssrn.1619847 Technology Diffusion”, Kyklos, Vol. 59, N², pp. 307-321.

Venkatesh V, Morris MG (2000). Why don't men ever stop to ask for directions? Gender, social influence and their role in technology acceptance and usage behavior.MIS Quarterly, 24, 1, 115-139.

Vikas and Nath (2000) "The Global Information and Information Technology" Report 2001 - 2002, InfoDev. World Bank. Vol. 56, №3, pp. 341-360.

Ward, M.R. (2010), "Learning to Surf: Spillovers in the Adoption of the Internet", Available at Waverman, L., Meschi, M., Fuss, M. (2005), "The Impact of Telecoms on Economic Growth in Developing Countries" in Africa: The Economic Impact of Mobile Phones. Vodafone Policy Paper Series, Number 3. 